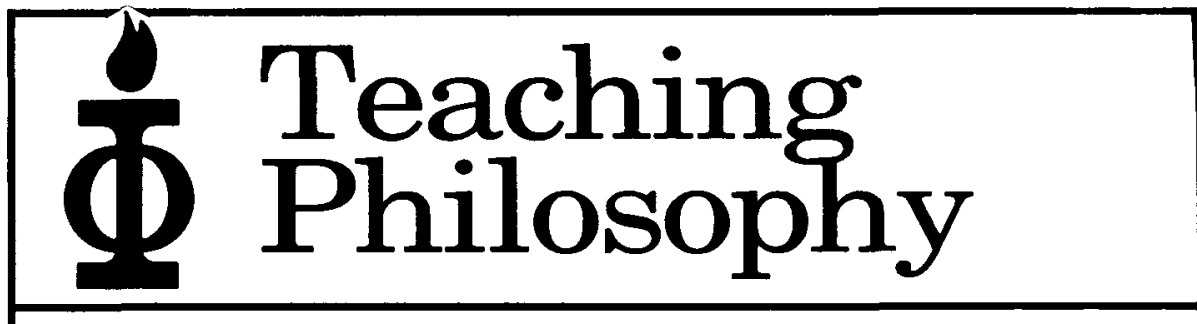

What the Reviewers Say:

"Recognized as the most comprehensive and varied source of infor:mation on all aspects of philosophy teaching. . . highly readable. . . meticulously edited."

—Guidebook for Publishing Philosophy, APA 1986

"Fresh and lively. . .maintaining high standards."

-Informal Logic, 1984

"Important for libraries supporting philosophy programs." .

-Magazines for Libraries, 3rd ed.

"The large number of book reviews, and their focus on appropriateness for undergraduates, is a very positive feature of the journal. . . useful wherever the teaching of philosophy is given attention."

-Choice, 1979

"Because it provides invaluable aid to everyone involved in philosophic instruction, [it is] strongly recommended to any academic library supporting philosophy as part of its curriculum."

-Serials Review, 1976

As a forum for the exchange and evaluation of ideas and information about the teaching and learning of philosophy, Teaching Philosophy publishes articles, discussions, reports, and reviews on these and related topics:

1. Theoretical issues in the teaching of philosophy. What is the relation between philosophy and its teaching? What should be the nature of philosophy curricula, courses, and pedagogy? What special pedagogical problems are there for teachers of philosophy?

2. Innovative methods, classroom stratagems, the use of new materials.

3. Experimental and interdisciplinary courses with philosophical content, or that develop the philosophical aspects of other fields.

4. Evaluation of teaching and assessment of learning in philosophy. Faculty development and student counseling in philosophy.

5. New books and audio-visual materials of interest to teachers of philosophy.

Subscription information for 1988: (4 issues): $\$ 18.50$ individuals; $\$ 42$ others. Add $\$ 4$ for postage outside the USA. Send orders to the Philosophy Documentation Center, Bowling Green State University, Bowling Green, OH 43403-0189 USA.

Edited by: Arnold Wilson, Department of Philosophy, University of Cincinnati, Cincinnati, $\mathrm{OH} 45221-0206$. 


\section{THE PHILOSOPHICAL QUARTERLY}

\section{Editorial Chairman: Neil Cooper Acting Executive Editor: Roger Squires}

Founded by the Scots Philosophical Club and the University of St Andrews in 1950, The Philosophical Quarterty aims to foster and publish significant contributions in every branch of the subject, promoting discussion of recent philosophical works, and providing critical reviews of recent books, in a style accessible to as wide a group of philosophers as possible.

Published April, July, October for the Scots Philosophical Club and the University of St Andrews

Subscription Rates Volume 38, 1988

Individuals: $£ 12.00$ (UK) $£ 15.00$ (overseas) US $\$ 28.50$ (N. America)

Institutions: $\mathbf{E} 30.50$ (UK) $\mathbf{E} 40.75$ (overseas) US\$68.25 (N. America)

Rates include inland or accelerated surface postage.

Please send orders with payment to:

Iris Taytor

Joumals Department

Basil Blackwell

108 Cowley Road

Oxford OX4 1JF

England

\author{
or to: Journals Department \\ Basil Blackwell \\ PO Box 1320 \\ Murray Hill Station \\ NY 10156 \\ USA
}

\section{Basil Blackwell · Oxford and New York}

\section{Bioethics}

\section{CALL FOR PAPERS}

\section{Special Issue for 1989}

\section{The Scientific, Philosophical and Ethical Uncertainties of Pain}

There is a range of issues relating to pain which cross the boundaries of science, philosophy of mind and ethics, and have implications for our treatment of foetuses, infants, older humans in abnormal conditions, and non-human animals. What can we know about whether, and to what degree, beings in these categories can feel pain? And what are the ethical implications of any uncertainty we may have about the pain they feel?

We invite contributions on any aspect of these issues, or on related ethical problems in biomedical research or medical or veterinary practice. Such problems include, but are not limited to, animal experimentation, medical uses of the human foetus, late abortions, and painful procedures on newborn infants and on older patients who are unable to consent. Contributors who are in doubt about whether their topic will be suitable for the issue are invited to send us an outline of their work.

The deadline for submission of papers is January 15, 1989.

Helga Kuhse and Peter Singer, Centre for Human Bioethics, Monash University, Clayton, Victoria 3168 , Australia. 


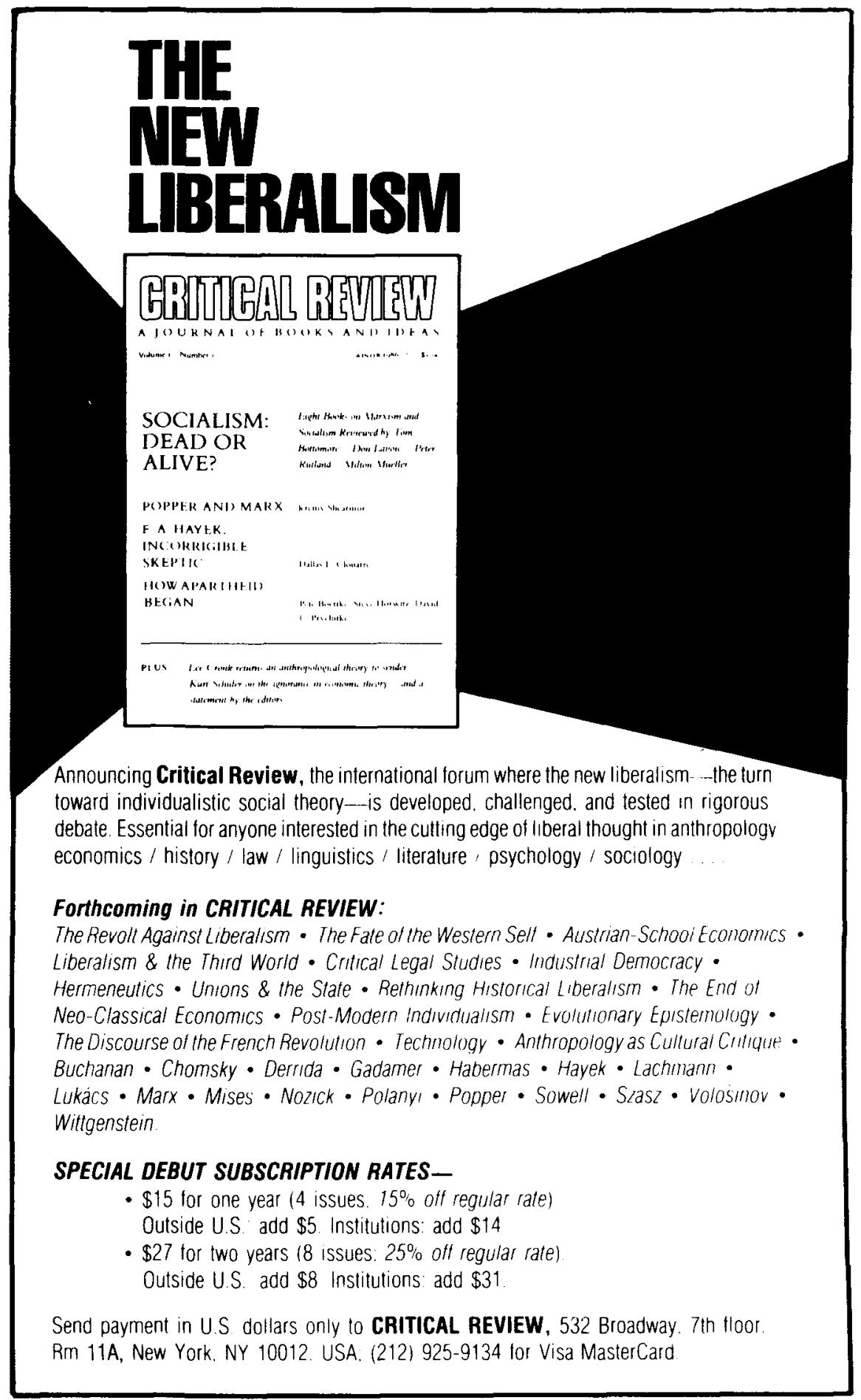




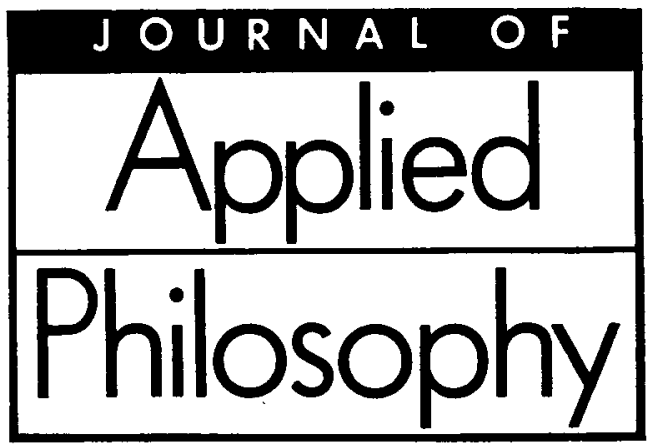

This journal provides a focus for philosophical research with a direct bearing on areas of practical concern which are capable of being illuminated by the critical analytical approach characteristic of philosophy, and by direct consideration of questions of value. These areas include law, politics, economics, science-policy. medicine and education, but are not confined to these. The journal, published under the auspices of the Society for Applied Philosophy, aims to foster and promote philosophical work which is intended to make a constructive contribution to problems in these areas and to the identification. justification and discussion of values capable of transcending narrow or local interests.

\section{EDITORS}

\section{Brenda Almond \& Anthony O'Hear}

EDITORIAL BOARD

Sir Alfred Ayer; Robin Barrow; Stephen R.L. Clark; David E. Cooper; Raanan Gillon:

James Griffin; R.M.Hare; Martin Hollis; Ian Kennedy; Joel Kupperman; Jeff McMahan; Mary Midgley; John Passmore; Philip Pettit; Alan Ryan; Amartya Sen; Peter Singer; T.L.S. Sprigge; Richard Tur.

\section{EDITORIAL ADVISERS}

\section{Bernard S. Baumrin (USA) \& Keith Campbell} (Australia)
Volume 5 Number 1 March 1988

Brenda Almond/Human Bonds Joseph Agassi/The Future of Big Science

Beverley Shaw/Poverty: absolute or relative?

\section{Timo Airaksinen/Original}

Populations and Environmental Rights Nigel L. G. Eastman and R. A.

Hope/The Ethics of Enforced Medical Treatment: the balance model

David Greaves/Sudden Infant Deaths: models of health and illness

Edmund Wall/Intention and Coercion

\section{DISCUSSION ARTICLES}

\section{J. Martin Stafford/Love and Lust} Revised: intentionality, homosexuality and moral education

Donald Hill/On Reasoning Morally about the Environment

Celia Wolf-Devine/An Inequity in Affirmative Action

David Conway/ls Failing to Save Lives as Bad as Killing?

Christopher Winch/The Honey

Trap: the social and cognitive adequacy of language in educational contexts

The journal is published twice a year. in March and October. These two annual issues constitute one volume. An annual index and title page is bound in with the October issue. Volume $5-1988$. ISSN 0264-3758.

\section{Subscription rates (post free): one} year (one volume) \&46.00 (UK). US\$114.00 (Rest of the World). Individuals receiving the journal at a private address may subscribe at a $50 \%$ discount-i.e. $£ 23.00$ (UK). US $\$ 57.00$ (Rest of the World).

Please enter our subscription to Journal of Applied Philosophy

We enclose $\mathrm{f} / \mathrm{US} \$$

Please enter my subscription under the terms of the Personal Subscription Plan (please give private address)

- I enclose $\mathrm{E} / \mathrm{US} \$$

Please charge Visa/MasterCard/Eurocard/Access/American Express No

Please send an inspection copy

Name

Address 


\section{Philosophy EPublic Affairs}

"PHILOSOPHY \& PUBLIC AFFAIRS was created to promote the discussion of matters of public concern, and to bridge the gap that exists between philosophers and those in other disciplines who are working on questions that raise philosophical issues. The journal has maintained a high level of discussion from the start." - Peter Singer, The New York Times Magazine

Articles from recent issues include:

Egoists, Consequentialists, and Their Friends by William $\mathrm{H}$. Wilcox

Liberalism, Neutrality, and Equality of Welfare vs. Equality of Resources by Larry Alexander and Maimon Schwarzschild

Exploitation, Force, and the Moral Assessment of Capitalism: Thoughts on Roemer and Cohen by Jeffrey Reiman

Justice and Gender by Susan Moller Okin

Intransitivity and the Mere Addition Paradox by Larry S. Temkin

Foundationalism in Political Theory by Arthur Ripstein

\section{Enter your Subscription now.}

Philosophy

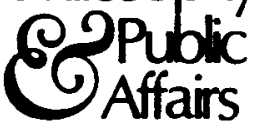

Subscriptions

Princeton University Press

3175 Princeton Pike Lawrenceville, N I 08648

Institutional and foreign rates slightly higher.

foreign postage and handling rate $\$ 3.50$ year.

Name

Address 


\section{Social Theory and Practice}

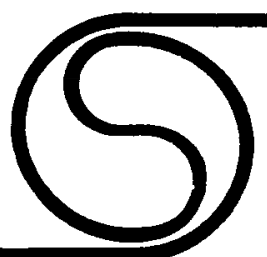

An International and Interdisciplinary Journal of Social Philosophy

Volume 13, Number 1 Spring 1987

Man and People: The Problem of the Individual in Non-Narxian llistorical Materialism

Lcszek Nowak

Hypothetical Cases and Abortion

Don S. Lcvi

Personal Continuity and Instrumental Rationality in Rawls' Theory of Justice Adrian M.S. Piper

Some Implications of Comparable Worth

Lauric Shrage

On a Woman's "Responsibility" for the Fetus Harry S. Silverstcin 


\section{STUDIES IN HISTORY \& PHILOSOPHY OF SCIENCE}

Editor: NICIIOLAS JARDINE, Department of IHistory \& Philosophy of Scichee, University of Cambridge, Free School Lane, Cambridge CB2 3RII, UK Scnior Consulting Editor: GERD BUCIIDAHL Department of Ilistory \& Philosophy of Science, University of Cambridgc, Free School Lane, Cambridge CB2 3RII, UK

Book Review Editor: JENNY WARD.

Studics in Ilistory o Philosophy of Scicnce is essential reading for students and Ieachers concerned with the historical, social and intellectual contexts of the sciences and with their methodology and epistemology.

The journal particularly encourages studies which integrate philosoplical, historical and sociological consideralions. fis orientation is international, with contributions from a wide range of cultural perspectives.

The papers published are of the highest scholarly qualily. Since the journal's inception it has proved an invaluable source both for reflective scientists and for workers in the history, philosophy and sociology of science.

Relevant papers are welcome for editorial consideration.

\section{A Selection of Papers}

On the dynamics of mathemalical change in the case of Monge and the french Revolution, E GLAS (The Netherlands).

Berkeley, Newlon and the stars, K P WINKIER (USA).

How do scient ists reach agrecment about novel observations? D GOODING (Uli).

James J Gibson's revolution in perceptual psychology: a calse study of the

Iransformation of scicntific idcas, ES REED (USA).

Aether/Or: the creation of scientific concepts, N J NERSESSIAN (lihe Netherlands). lighl hypotheses, I'ACIIINSTEIN (USA).

Jesuit mathematical science and the reconstitution of experience in the early seventecenth century, PDEAB (USA).

I're-lineoretical aspects of Arislotelian definition and elassification of animals: the case for common scusc, S ATKAN (France).

The later work of E Sclırödinger, B IBERTOTTI (Ilaly).

Mach's theory of research and its reliation to Einslein, I' K FEYERABEND (USA).

\section{Subscription Information}

1988: Volume 19 (4 issues)

Ammal subscription (1988)

DM 320.00

'Two-year rale (1988/89)

DM 608.00

ISSN: 0039-3681

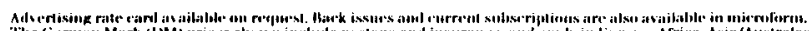

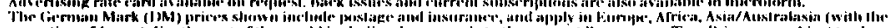

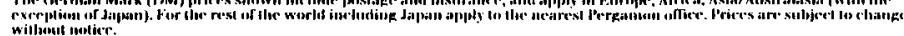

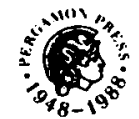

\section{P E R G A M O N PRE S S}

lleadinglon llill Ilall, Oxford OX3 0BW, UK Fairview l'ark, Elmsford, New York 10523, USA 


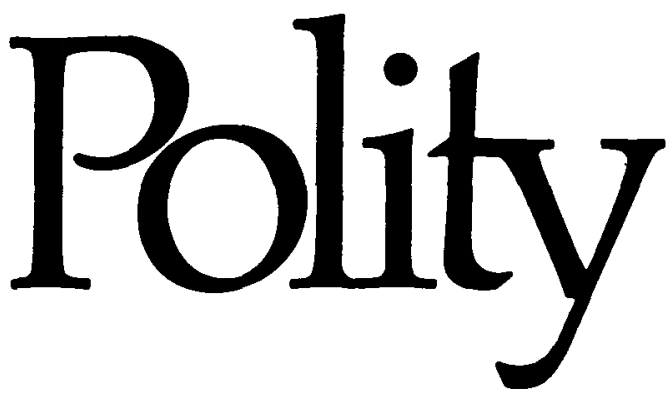

What's in a name?

1: political organization: civil order. . 2a: a specific form of political organization: a form of government... b: an Aristotelian form of political organization in which the whole body of the people govern for the good of all and that constitutes a fusion of oligarchy and democracy 3: the management of public and private affairs; esp. prudent, shrewd, or crafty administration. . .4: a politically organized unit (as a nation, state, or community)...5: the form or constitution of a politically organized unit (as a nation or state)...b: the form of government or organization of $a$ religious denomination...

6: THE JOURNAL OF THE NORTHEASTERN POLITICAL SCIENCE ASSOCIATION

\section{Subscription Rates}

Individuals: $\$ 20.00$ (including membership in the Northeastern Political Science Association)

Foreign: $\$ 22.00$

Institutions: $\$ 35.00$, Foreign: $\$ 36.00$

Student: U.S.A. $\$ 7.00$, Foreign: $\$ 10.00$

Mail (subscription orders) to: POLITY. Thompson Hall, University of Massachusetts, Amheršt, Massachusetts 01003

Name

Address

Payment enclosed, sum of: 
Photocopying. Permission is granted by the publisher for those institutions registered with the Copyright Clearance Centre to authorize internal photocopying of any article in this journal for a fee of $\$ 2.00$ per copy per article. Payment should be made direct to: Copyright Clearance Centre, 21 Congress Street, Salem, Massachusetts 01970, USA. Individuals, or institutions not registered with the CCC, must obtain permission to photocopy either from the CCC or from Basil Blackwell (address above), when the same fees will apply.

Advertising. For details contact the Advertisement Manager, Bill Drake, telephone 086938477 or write $\mathrm{c} / \mathrm{o}$ the publishers.

All contributions to Social Philosophy E Policy through Volume 5 will be sunciteu oy the editors. We regret that unsolicited manuscripts cannot be considered for these issues. As stated on the back cover of this issue, Volume 6 will be comprised largely of unsolicited manuscripts (approximately 80 percent). Our readers will be notified of the submission policy on subsequent issues.

Typeset by Columns of Reading

Printed in Great Britain by Whitstable Litho 


\section{CALL FOR PAPERS}

The editors of Social Philosopliy \& Polity are pleased to announce that Volume 6 , Issues 1 and 2 will be open to unsolicited manuscripts. Issue 1 will be devoted to the theme "Capitalism" and Issue 2 to "Socialism." Papers can address such themes as: the morality of capitalism (or socialism); the defensibility of either system; the morality or efficiency of a particular aspect of doctrine of either system; or they may critically examine either system. These are broad suggestions only, and paper topics ought to be more narrowly defined. The deadlines for the two issues are:

Submissions- of papers

Capitalism

Socralism
- June 1, 1987

January 1, 1988
Notification of authors of acceptance or rejection January 1, 1988 July 1, 1988
Publication date

Fall 1988

Spring 1989

- Papers should be double spaced with all footnotes collected at the end of 'the paper, and foothotes must, conform to the Chicago Mainal of Style. Papers exceeding 30 typewritten pages cannot be considered. Three copies should be submitted: they will not be returned unless accompanied by a stamped self-addressed envelope. Since papers will be blind-reviewed, authors, should only be identified on a removable coversheet, and all references to the author should be in the third person. All papers should be accompanied by a 100 -word summary, also in triplicate. Only successful papers will receive detailed referees' comments. Please send papers to:

Johrr Ahrens, Managing Editor

Social Philosophy \& Policy

Social Philosophy and Policy Center

Bowling Green State University.

Bowling Green, OH 43403

- Please feel free to eontact the editors if you would like additional guidance. 